\title{
Ilhas e oceanos: espaços de campo e laboratório
}

\author{
Islands and oceans: field and laboratory spaces
}

\author{
Maria Margaret Lopes \\ Professora convidada, Pagu - Núcleo de Estudos de Gênero/Universidade Estadual de Campinas e \\ Programa de Pós-graduação em Ciência da Informação/Universidade de Brasília. \\ mariamargaretlopes@gmail.com
}

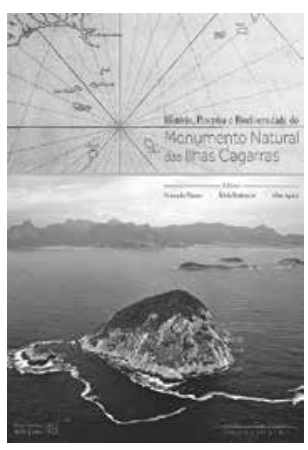

MORAES, Fernando; BERTONCINI, Áthila; AGUIAR, Aline. História, pesquisa e biodiversidade do Monumento Natural das Ilhas Cagarras. Rio de Janeiro: Museu Nacional. 2013. 300p.
$\mathrm{O}^{\mathrm{n}}$ Projeto Ilhas do Rio, com o selo da série Livros do Museu Nacional, patrocinado pela Petrobras, traz agora a obra editada por Fernando Moraes, Áthila Bertoncini e Aline Aguiar dedicada à memória do professor Gustavo Nunam, ictiólogo do Museu Nacional um dos pioneiros na proposta de tornar as ilhas das Cagarras uma unidade de conservação. A obra coletiva contou com a participação de quase quarenta pesquisadores e cerca de sessenta coletores das instituições do Rio de Janeiro e do país. Já no seu prefácio, o professor Jean Louis Valentin, da Universidade Federal do Rio de Janeiro, destacou a importância, que marca o conjunto dos artigos, da conscientização sobre a fragilidade desse fantástico ecossistema.

O livro ilustra, de maneira magnífica, as pesquisas científicas realizadas e em andamento no arquipélago com aquarelas, detalhes de mapas franceses e portugueses que remontam a 1750 e quase quinhentas fotografias - incluindo um grande número de belíssimas imagens aéreas e submarinas. As pesquisas abrangem arqueologia, geomorfologia, biogeografia, qualidade das águas, turismo e lazer. Há um equilíbrio na escolha dos 12 capítulos, que discutem da caracterização física e biológica até a demonstração da presença humana desde tempos pré-coloniais - por exemplo na ilha Redonda. A caracterização das ilhas e do seu entorno abrange os estudos de algas marinhas, flora terrestre vascular, peixes dos recifes, avifauna, baleias e golfinhos, fauna terrestre, além dos capítulos sobre o monitoramento ambiental e as atividades humanas.

Como não poderia deixar de ser, a curiosidade sobre a denominação das diversas ilhas e ilhotas do arquipélago é objeto de considerações sobre a origem da toponímia, desde pelo menos a cartografia do século XVII, com as variações de nomes com que foi conhecida ao longo do tempo, entre elas a de ilha Tapera (o que já apontava para a presença humana indígena), ilha Comprida, ilha das Palmas etc. Mais importante, devido à proximidade do 
arquipélago da costa da cidade do Rio de Janeiro (mais especificamente, da praia de Ipanema), é que diversos autores enfatizaram e aprofundaram estudos a respeito do impacto humano sobre o monumento natural: desde as incipientes pesquisas de arqueologia, abordagens de aspectos do monitoramento da qualidade das águas e dos poluentes, até atividades pesqueiras e o potencial de turismo, esporte e lazer, importância ecológica e econômica da região, ameaças à biodiversidade ou espécies ameaçadas de extinção.

Os monumentos naturais como as ilhas Cagarras constituem loci de novos e dos mais diversos interesses de estudiosos e de públicos. Tanto a possível descobertas de espécies inéditas para a ciência como a possibilidade do acompanhamento ao longo do tempo de medições de parâmetros biológicos, físicos e químicos sobre a água do mar são aspectos importantes ressaltados no livro. Em um momento no qual a "sustentabilidade" tornou-se uma palavra de ordem, e em que as comunidades de cientistas e grupos de cidadãos organizados alertam para os desafios ecológicos em escala global, o privilégio e a responsabilidade frente a um local tão rico e diverso distante apenas alguns quilometros da costa do Rio de Janeiro não podem ser descartados por nós.

Não faltam no texto os exemplos do potencial econômico de pesquisas farmacológicas, como o estudo de substâncias ativas com propriedades antivirais e antifúngicas presentes em organismos marinhos (por exemplo, as macroalgas). Estão presentes também as informações sobre o impacto do emissário submarino, da poluição proveniente da grande navegação, da pesca predatória e do turismo selvagem que constituem ameaças a esses frágeis ecossistemas. Do ponto de vista legal, as ilhas estão sob a proteção da União, graças a sua denominação de Unidade de Conservação Federal de Proteção Integral, conforme a lei 12.229, de 13 de abril de 2010. O Monumento Natural das Ilhas Cagarras é uma das 313 unidades de conservação federais sob a tutela e gestão do Instituto Chico Mendes de Conservação da Biodiversidade e uma das 59 unidades do bioma marinho - uma área marinha de apenas dez metros ao redor das ilhas e ilhotas do arquipélago também está protegida.

O livro identifica, apoiado em imagens por satélite, as 25 estações de coleta marinhas e as 18 estações de coletas terrestres, e mostra, didaticamente, em que consiste a coleta de dados no campo e no laboratório, dentro de uma perspectiva multidisciplinar inovadora. Nesse sentido, o trabalho de identificação de espécies contou com a expertise da comunidade de pescadores artesanais da Colônia de Copacabana (Z-13), que comercializa uma centena de espécies, dentre as mais de seiscentas identificadas pela equipe e listadas no livro.

A exaustiva bibliografia ao fim do volume inclui mais de 580 referências de artigos científicos que subsidiaram os pesquisadores nessa obra na qual a importância científica é inegável, e o chamado à responsabilidade, inédito.

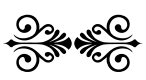

